\title{
Karolina Lopacińska
}

Uniwersytet Ekonomiczny we Wrocławiu

e-mail: lopacinska.karolina@gmail.com

\section{INWESTYCJE BEZPOŚREDNIE CHIŃSKICH PRZEDSIĘBIORSTW NA RYNKU EUROPEJSKIM W PRZEKROJU BRANŻ}

\begin{abstract}
Streszczenie: Postępująca ekspansja chińskiej gospodarki umacnia pozycję Chin na międzynarodowym rynku. Chiny dominują na świecie pod względem wielkości eksportu, a liczba bezpośrednich inwestycji firm chińskich, skierowanych do rozwiniętych krajów europejskich, również znacznie wzrosła. Przedmiotem artykułu będzie rozwój inwestycji bezpośrednich w krajach Europy, w tym zwłaszcza w rozwiniętych krajach europejskich, z koncentracją na takich krajach, jak: Francja, Wielka Brytania oraz Niemcy. To właśnie w tych państwach chińscy inwestorzy spodziewają się osiągać najwyższe przychody. W artykule została przedstawiona struktura branżowa chińskich inwestycji bezpośrednich w Europie, z koncentracją na wybranych przykładach porozumień tego typu nawiązanych między inwestorami z Chin i z krajów europejskich. Na tej podstawie podjęta została próba określenia wpływu zawartych fuzji na pozycję przedsiębiorstw na rynku europejskim.
\end{abstract}

Slowa kluczowe: bezpośrednie inwestycje zagraniczne, fuzje, przejęcia, chińska ekspansja.

DOI: $10.15611 / \mathrm{pn} .2014 .369 .1 .25$

\section{Wstęp}

Postępująca ekspansja chińskiej gospodarki umacnia pozycję Chin na międzynarodowym rynku. Chiny dominują na świecie pod względem wielkości eksportu', a liczba bezpośrednich inwestycji firm chińskich, skierowanych do rozwiniętych krajów europejskich również znacznie wzrosła. Przedmiotem artykułu jest rozwój inwestycji bezpośrednich w krajach Europy, w tym zwłaszcza w rozwiniętych krajach europejskich, z koncentracją na takich krajach, jak: Francja, Wielka Brytania oraz Niemcy. To właśnie w tych państwach chińscy inwestorzy spodziewają się osiągać najwyższe przychody. Celem artykułu jest przedstawienie rozmieszczenia

${ }^{1}$ K.A. Nawrot, Kierunki inwestycji Chin. Jakich inwestycji chińskich może oczekiwać Polska, Poznań 2012. 
chińskich inwestycji bezpośrednich w Europie w przekroju branż, z koncentracją na wybranych przykładach porozumień tego typu nawiązanych między inwestorami z Chin i z krajów europejskich. Na tej podstawie podjęta zostanie próba określenia wpływu zawartych fuzji na pozycję przedsiębiorstw na rynku europejskim. Podstawą dokonywanych w artykule analiz i rozważań są raporty Rhodium Group, Center for European Reform oraz raporty finansowe firm będących przedmiotem analizy, jak również dane statystyczne pozyskane m.in. ze stron Institute of Mergers, Acquisitions and Alliances, European Chamber of Commerce in China, Reuters oraz Heritage Foundation.

\section{Struktura branżowa fuzji z kapitałem chińskim na rynku europejskim}

Roczne wpływy do budżetu Chin z bezpośrednich inwestycji w latach 2006-2009 wzrosły trzykrotnie, a tempo tego wzrostu zostało utrzymane do roku 2011. W efekcie poziom eksportu wyniósł 10 mld dolarów rocznie. Równocześnie liczba transakcji o wartości ponad $1 \mathrm{mln}$ dolarów wzrosła dwukrotnie - z ok. 50 transakcji do prawie 100, zarówno w roku 2010, jak i 2011.

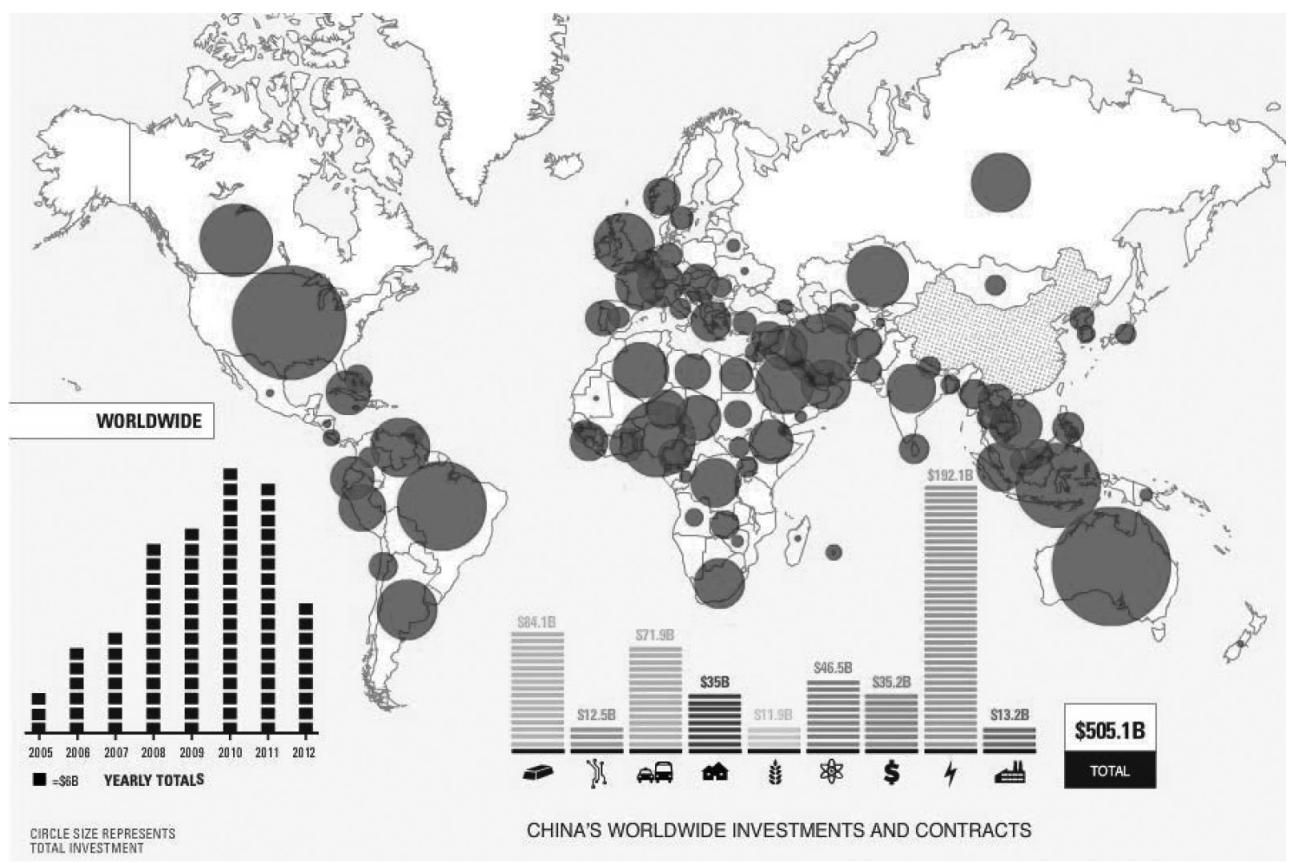

Rys. 1. Światowy zasięg bezpośrednich inwestycji chińskich przedsiębiorstw w przekroju branż Źródło: The Heritage Foundation, http://www.heritage.org// (12.02.2014). 
Skalę bezpośrednich inwestycji przedsiębiorstw chińskich w latach 2005-2012 przedstawiono na rys. $1^{2}$. Bezpośrednie inwestycje zagraniczne stanowią filar europejskiej integracji gospodarczej i politycznej od ok. 50 lat. W główniej mierze w oparciu o nie i o ogólną wymianę handlową doszło do nawiązania i rozwoju relacji między Unią Europejską a Chinami. Implementacja reform, mających na celu otwarcie chińskiej gospodarki na świat, jak i wprowadzenie w życie strategii „Go Global” w 1999 roku oraz wstąpienie Chin w 2001 roku do Światowej Organizacji Handlu (WTO) miały również istotny wpływ na ukształtowanie wzajemnych stosunków. Relacje między UE a Chinami rozwijają się w różnych wymiarach, tj. zarówno w wymiarze gospodarczym, jak i politycznym czy kulturowym. Rosnąca współzależność tych podmiotów, dążących do osiągnięcia możliwie najwyższego wzrostu i rozwoju gospodarczego, a także innych profitów związanych z korzystaniem z wzajemnego potencjału, pozwoliła im stworzyć drugie co do wielkości największe partnerstwo gospodarcze na świecie ${ }^{3}$.

Istnieje wiele motywów podejmowania przez przedsiębiorstwa inwestycji na zagranicznych rynkach. Do głównych przesłanek ekspansji Chin w Europie możemy zaliczyć dążenie do ułatwienia chińskiego eksportu przez ominięcie barier handlowych, na które napotykają firmy sprowadzające towary do UE, ale przede wszystkich chęć uzyskania strategicznych udziałów w firmach z sektorów wysokiej i średniej techniki. Oprócz tego jest szczególnie ważne z punktu widzenia aspiracji Chin, by do 2020 roku stać się największą gospodarką zaawansowaną technologicznie. Szczegółowy rozkład inwestycji realizowanych przez firmy chińskie w poszczególnych krajach, ze szczególnym uwzględnieniem inwestycji greenfield, został zaprezentowany w tab. 1.

Większość inwestycji dokonywanych przez chińskie przedsiębiorstwa w latach 2000-2011 była skierowana do krajów UE-15, a w szczególności do trzech największych gospodarek europejskich, tj.: francuskiej, brytyjskiej i niemieckiej. Jak wynika $\mathrm{z}$ danych zawartych $\mathrm{w}$ tab. 1 we Francji chińscy przedsiębiorcy zawarli w tym okresie 70 umów o łącznej wartości 5,7 mld dolarów, w tym aż 3,2 mld dolarów zostało zainwestowanych w roku $2011 \mathrm{w}$ firmę Gas de France. W Wielkiej Brytanii zostało zawartych 95 umów o wartości 3,7 mld dolarów, głównie w takich sektorach, jak motoryzacja, bankowość i nieruchomości. Niemcy przyciągnęły ponad jedną trzecią wszystkich zawartych w Europie umów o łącznej wartości 2,5 mld dolarów. Krajami zajmującymi wysoką pozycje w rankingu pod względem chińskich inwestycji są również Węgry i Grecja. Na Węgrzech chińska firma dokonała inwestycji w sektorze chemicznym, zakupując akcje węgierskiego producenta izocyjanianów

${ }^{2}$ T. Hanemann, D.H. Rosen, China invests in Europe. Patterns, Impacts and Policy Implications, Rhodium Group, 2012.

3 K.A. Nawrot, wyd. cyt.; China deals. A fresh perspective, 2012, www.pwc.co.uk/china/./ (10.02.2014); C. Grant, K. Barysch ,Can Europe and China shape a new world order?, Centre for European Reform, http://www.cer.org.uk/publications/archive/report/2008/can-europe-and-china-shapenew-world-order. 
Inwestycje bezpośrednie chińskich przedsiębiorstw na rynku europejskim w przekroju...

Tabela 1. Inwestycje chińskich przedsiębiorstw w krajach europejskich UE-27 w latach 2000-2011

\begin{tabular}{|c|c|c|c|c|}
\hline Kraj & $\begin{array}{l}\text { Wartość inwestycji } \\
\text { (w USD) }\end{array}$ & $\begin{array}{l}\text { Liczba projektów } \\
\text { greenfield }\end{array}$ & Liczba przejęć & $\begin{array}{l}\text { Liczba umów } \\
\text { w sumie }\end{array}$ \\
\hline Francja & 5,722 & 46 & 24 & 70 \\
\hline Wielka Brytania & 3,683 & 69 & 26 & 95 \\
\hline Niemcy & 2,543 & 113 & 33 & 146 \\
\hline Szwecja & 2,251 & 14 & 6 & 20 \\
\hline Węgry & 2,065 & 14 & 4 & 18 \\
\hline Holandia & 1,164 & 32 & 15 & 47 \\
\hline Belgia & 847 & 12 & 3 & 15 \\
\hline Grecja & 714 & 5 & 0 & 5 \\
\hline Włochy & 554 & 31 & 16 & 47 \\
\hline Austria & 391 & 6 & 5 & 11 \\
\hline Rumunia & 299 & 13 & 1 & 14 \\
\hline Polska & 190 & 15 & 1 & 16 \\
\hline Hiszpania & 187 & 22 & 1 & 23 \\
\hline Czechy & 76 & 10 & 1 & 11 \\
\hline Finlandia & 48 & 1 & 4 & 5 \\
\hline Portugalia & 47 & 5 & 0 & 5 \\
\hline Bułgaria & 47 & 6 & 1 & 7 \\
\hline Luksemburg & 46 & 1 & 1 & 2 \\
\hline Irlandia & 44 & 6 & 1 & 7 \\
\hline Dania & 30 & 6 & 1 & 7 \\
\hline Łotwa & 3,8 & 1 & 0 & 1 \\
\hline Cypr & 3 & 0 & 1 & 1 \\
\hline Estonia & 0 & 0 & 0 & 0 \\
\hline Litwa & 0 & 0 & 0 & 0 \\
\hline Malta & 0 & 0 & 0 & 0 \\
\hline Słowacja & 0 & 0 & 0 & 0 \\
\hline Słowenia & 0 & 0 & 0 & 0 \\
\hline RAZEM & 20,957 & 428 & 145 & 573 \\
\hline
\end{tabular}

Źródło: T. Hanemann, D.H. Rosen, China Invests in Europe. Patterns, Impacts and Policy Implications, Rhodium Group, 2012.

Borsodchem warte 1,9 mld dolarów. Grecja z kolei oddała w długoterminową dzierżawę chińskiemu COSCO swój największy port grecki w Pireusie, co przyczyniło się do szybkiego rozwoju portu na skutek wielu inwestycji COSCO wartych miliony euro. Wraz z rozwojem działalności w Pireusie chińskie COSCO zdecydowało się w 2013 roku na dodatkowe inwestycje, których łączna wartość wyniesie $500 \mathrm{mln}$ 
euro, a Pireus będzie miał w najbliższych latach zdolność do obsługi do 6,2 mln TEU (objętość kontenera) rocznie, tj. trzy razy więcej niż w roku $2012^{4}$.

Ponadto w rankingu pod względem liczby i wartości zlokalizowanych chińskich inwestycji wysokie lokaty zajęły również takie kraje, jak Szwecja, dzięki, wartemu 1,5 mld dolarów przejęciu Volvo Cars przez chiński koncern samochodowy Geely Automobile i późniejszym wynikającym z niego inwestycjom, oraz Rumunia za sprawą kilku inwestycji produkcyjnych greenfield, a wśród nich budowy zakładu do produkcji ciągników przez chińską firmę Shantuo Agricultural Machinery Equipment. Kraje o znacznie mniejszej liczbie chińskich inwestycji, a co za tym idzie, niższych pozycjach w rankingu, to m.in. Hiszpania, Luksemburg, Dania i Irlandia. Hiszpania i Irlandia były niegdyś głównymi kierunkami inwestycji zagranicznych, lecz ich gospodarki niestety podupadły dokładnie w okresie chińskiego boomu inwestycyjnego, przez co kraje te straciły w oczach chińskich inwestorów, tak jak i inne mniejsze kraje europejskie stojące w obliczu problemów fiskalnych i strukturalnych, z wyjątkiem Grecji.

Patrząc jednak w przyszłość, prywatyzacja majątku państwowego w krajach fiskalnie niepewnych może zapewnić atrakcyjne możliwości chińskim inwestorom. Aktywa o stabilnym długoterminowym zwrocie z inwestycji, takie jak elementy infrastruktury, są bowiem przedmiotem zainteresowania chińskich inwestorów nastawionych na działalność długoterminową, czego przykładem jest chociażby sprzedaż na początku roku 2012 udziałów portugalskich przedsiębiorstw użyteczności publicznej o wartości 2 mld dolarów chińskim firmom5.

\section{Przykłady fuzji przedsiębiorstw na rynku europejskim - podstawowe charakterystyki}

Wybuch globalnego kryzysu gospodarczego odbił się bardzo niekorzystnie na wielu krajach świata. W przypadku Chin przyczynił się on jednak do znaczącego wzrostu liczby zagranicznych inwestycji bezpośrednich. Ich wartość równa 55,9 mld USD w roku 2008 uległa podwojeniu w porównaniu z 26,5 mld USD uzyskanymi w roku 2007, a 68,8 mld USD w roku 2010 dało Chinom piąte miejsce pod względem skali realizowanych na świecie bezpośrednich inwestycji zagranicznych. Najwięcej zróżnicowanych pod względem branż inwestycji chińskich zlokalizowanych zostało na rynkach Azji i Europy. Inwestorzy są bowiem zainteresowani inwestowaniem w wiele dziedzin, a w szczególności w te ujęte w XII pięcioletnim planie gospodarczym jako priorytetowe. Należą do nich sektory: technologii energetycznych, biotechnologii, nowej generacji technologii informacyjnych, przemysłu towarów wysoko przetworzonych, a także sektory nowych materiałów i alternatywnych źródeł energii oraz pojazdów na biopaliwa. W 2008 roku wzrosło zainteresowanie chiń-

\footnotetext{
4 www.news.xinhuanet.com/ (26.02.2014).

${ }^{5}$ T. Hanemann, D.H. Rosen, wyd. cyt.; China deals. A fresh perspective...
} 
skich inwestorów rynkiem europejskim zarówno pod względem lokowania na nim bezpośrednich inwestycji zagranicznych, jak i udziału w publicznych przetargach oraz zakupie obligacji. Wartość bezpośrednich inwestycji zagranicznych wynosiła wówczas 876 mln USD i wzrosła do 3,352 mld USD w 2009 roku, a następnie do

Tabela 2. Przykłady największych inwestycji z udziałem kapitału chińskiego w przekroju branż

\begin{tabular}{|c|c|}
\hline & Inwestycje \\
\hline \multirow[t]{5}{*}{ Sektor energetyczny } & $\begin{array}{l}\text { przejęcie przez Sinopec firmy Addax Petroleum z siedzibą } \\
\text { w Szwajcarii (7,2 mld USD - największe przejęcie przez } \\
\text { chińskie przedsiębiorstwo) }\end{array}$ \\
\hline & $\begin{array}{l}\text { - przejęcie przez Sinochem firmy Emerald Energy (Wielka } \\
\text { Brytania) }\end{array}$ \\
\hline & - przejęcie przez CNOOC firmy Awilco Offshore (Norwegia) \\
\hline & - zakup przez CNPC udziałów w INEOS (Francja) \\
\hline & $\begin{array}{l}\text { - zakup przez SAFE 1,6\% udziałów w Total (Francja) oraz 1\% } \\
\text { udziałów w BP (Wielka Brytania) }\end{array}$ \\
\hline \multirow[t]{5}{*}{ Sektor transportowy } & $\begin{array}{l}\text { przejęcie od Forda przez chiński koncern Zhejiang Geely } \\
\text { Holding Group udziałów w Volvo Car (Szwecja) }\end{array}$ \\
\hline & - przejęcie przez Great Wall Motors bułgarskiego Litex Motors \\
\hline & $\begin{array}{l}\text { - przejęcie przez China International Marine Containers firmy } \\
\text { Burg Industries (Holandia) }\end{array}$ \\
\hline & $\begin{array}{l}\text { - zakup przez Zhejiang Youngman Lotus i Pang Da Auto } \\
\text { udziałów w Spyker Cars (Holandia) }\end{array}$ \\
\hline & $\begin{array}{l}\text { - umowa COSCO Holdings na dzierżawę portu w Pireusie } \\
\text { (w planach są inwestycje w porcie w Neapolu) }\end{array}$ \\
\hline \multirow[t]{2}{*}{ Sektor przemysłowy } & $\begin{array}{l}\text { - zakup udziałów w firmach chemicznych BorsodChem } \\
\text { (Węgry) }\end{array}$ \\
\hline & - przejęcie Rhodia (Francja) \\
\hline \multirow[t]{2}{*}{ Sektor nieruchomości } & $\begin{array}{l}\text { - inwestycje w branży budowlanej Sany Heavy Industries } \\
\text { w Niemczech, Sinoma na Ukrainie, Zoomlion we Włoszech }\end{array}$ \\
\hline & $\begin{array}{l}\text { - w branży turystycznej inwestycje HNA w Hiszpanii, BCEGI } \\
\text { w Grecji }\end{array}$ \\
\hline \multirow[t]{4}{*}{ Sektor finansowy } & - zakup przez CITIC udziałów w Cheuvreux i CLSA (Francja) \\
\hline & - zakup przez CIC udziałów w Apax Finance (Wielka Brytania) \\
\hline & - zakup przez Ping An udziałów w Fortis (Belgia) \\
\hline & $\begin{array}{l}\text { - zakup przez China Development Bank udziałów w Barclays } \\
\text { (Wielka Brytania) }\end{array}$ \\
\hline \multirow[t]{2}{*}{$\begin{array}{l}\text { Sektor nowoczesnych } \\
\text { technologii }\end{array}$} & $\begin{array}{l}\text { - zakup przez China Unicom udziałów w hiszpańskiej } \\
\text { Telefonice }\end{array}$ \\
\hline & - przejęcie przez Lenovo niemieckiej firmy Medion \\
\hline
\end{tabular}

Źródło: www.gochina.gov.pl/ (20.02.2014). 
6,670 mld USD w roku 2010. Najwięcej chińskich inwestycji bezpośrednich zostało ulokowanych w takich europejskich krajach, jak Luksemburg (5,8 mld USD), Niemcy (1,5 mld USD), Szwecja (1,5 mld USD), Wielka Brytania (1,4 mld USD), Holandia (487 mln USD) oraz Węgry (466 mln USD). Polska plasowała się w tym rankingu na jednej z najwyższych pozycji spośród krajów Europy Środkowej z wartością chińskich inwestycji równą 140 mln USD. Kryzys w strefie euro, skutkujący istotnym obniżeniem ceny europejskich spółek oraz zmianą w polityce inwestycyjnej chińskich firm, spowodował ponowny silny wzrost zainteresowania rynkiem europejskim w roku 20116. Wykaz największych inwestycji bezpośrednich dokonanych w tym czasie przez firmy chińskie w Europie w poszczególnych sektorach został przedstawiony w tab. 2.

Jak widać $\mathrm{w}$ tab. 2, chińskie inwestycje są zlokalizowane w wielu różnych gałęziach przemysłu i usług. W czterech najważniejszych pod względem wartości sektorach dokonano przynajmniej jednego przejęcia na dużą skalę. W sektorze użyteczności publicznej wyróżnia się współpraca CIC z Gas de France, w przemyśle chemicznym przejęcie Borsodchem przez Wanhua, w sektorze transportowym przejęcie Volvo przez Geely, natomiast w sektorze energetycznym wykupienie Emerald przez Sinochem.

Analiza danych pokazuje relatywnie dużą dywersyfikację branżową chińskich inwestycji: od przemysłu maszynowego, przez telekomunikację, po dobra konsumpcyjne. Jednak biorąc pod uwagę liczbę zawartych transakcji, to przemysł maszynowy oraz sektor energii odnawialnej wzbudziły największe zainteresowanie chińskich inwestorów. Z uwagi na wysoką kapitałochłonność tych sektorów wartość inwestycji przedsiębiorstw chińskich nie jest jednak najwyższa w tych sektorach.

\section{Wpływ fuzji na pozycję przedsiębiorstw na rynku europejskim}

Inwestycje chińskich przedsiębiorstw w postaci fuzji i przejęć oddziałują na strukturę rynków, na których są realizowane, oraz wpływają na pozycję przedsiębiorstw objętych fuzją. O zmianie pozycji można wnioskować na podstawie procentowego udziału w rynku, wartości rynkowej firmy, wartości osiąganych przez nią przychodów, popularności marki i wizerunku.

W marcu 2010 roku doszło do fuzji, w wyniku której chińska firma Geely Automobile nabyła za 1,8 mld dolarów szwedzką markę Volvo od grupy Ford. Była to największa zagraniczna transakcja dokonana przez tę chińską firmę. Na podstawie umowy o transferze technologii Geely ma pełny dostęp do technologii Volvo, której wykorzystanie na chińskim rynku pozwoli na realizację jego strategicznych celów. Z użyciem technologii Volvo Geely planuje stworzyć nową markę Gelly Automobile dla chińskiego masowego odbiorcy. Relacje między tymi dwiema firma-

${ }^{6}$ www.gochina.gov.pl/ (20.02.2014); www.imaa-institute.org/ (20.02.2014); www.euccc.com.cn/ (20.02.2014). 
mi są określane jako partnerskie. Nie ma rywalizacji między tymi firmami, bo są one zorientowane na inne rynki docelowe. Geely sprzedaje auta z przeznaczeniem dla masowego odbiorcy, natomiast Volvo celuje w rynek produktów luksusowych. Współpraca Gelly i Volvo kształtuje się więc jak do tej pory stosunkowo dobrze. Geely Automobile odnotowało lepszy niż się spodziewano 13\% wzrost zysku netto w 2011 roku, a następnie 19\% w roku 2012, wykazując stały wzrost firmy. Liczba sprzedanych pojazdów, równa 483483 , była wyższa o $15 \%$ w porównaniu z rokiem 2011, z czego 21\% firma sprzedała na rynkach zagranicznych. Wyniki finansowe za rok 2012 przeszły wszelkie oczekiwania firmy, wzrosły bowiem o $17 \%$, prowadząc do systematycznej poprawy asortymentu oferowanych przez firmę produktów ${ }^{7}$. Sprzedaż Volvo w Chinach z kolei wzrosła we wrześniu o 14\%. Firma odnotowała silny wzrost zarówno w Chinach, jak i w Europie. Mimo strat odnotowanych przez Volvo na początku roku liczba aut sprzedanych we wrześniu wzrosła o 49\% w Chinach oraz o $24 \%$ w Europie, co sprawiło, że Chiny stały się w tym okresie największym rynkiem firmy ${ }^{8}$. W 2015 roku Geely i Volvo planują rozpocząć sprzedaż wspólnie opracowanych bezpiecznych i niezawodnych pojazdów. Chińska firma liczy, że pozwoli jej to dodatkowo wzmocnić reputację, dzięki osiągnięciu w kraju najwyższej pozycji eksportera samochodów osobowych. Szwedzka firma zaś, chcąc podwoić osiąganą wielkość sprzedaży do 800000 pojazdów w 2020 roku, rozpoczęła jazdy próbne w swojej pierwszej fabryce w Chinach. Ponadto obie firmy planują utworzenie w 2014 roku wspólnego centrum badań i rozwoju w Gothenburgu w Szwecji ${ }^{9}$. Kolejny przykład fuzji i przejęć z udziałem kapitału chińskiego dotyczy sektora energetycznego. W październiku 2009 roku nastąpiło przejęcie firmy energetycznej Emerald Energy PLC przez wiodącego sprzedawcę produktów chemicznych Sinochem Corp. Firma ta wykupiła notowaną na Londyńskiej Giełdzie firmę wydobywczą ropy naftowej i gazu za $532 \mathrm{mln}$ funtów, tj. 750 pensów za akcję, a więc o $11,1 \%$ więcej od cen akcji w momencie zamknięcia. Umowa zawarta między stronami miała chińskiej firmie umożliwić m.in. zoptymalizowanie struktury rezerw ropy naftowej i gazu, ponadto określić strategiczne rozmieszczenie wydobycia ich zasobów w Ameryce Południowej (Kolumbii) i na Bliskim Wschodzie (Syrii), a w efekcie stworzyć solidny fundament przyszłego rozwoju firmy w tych obszarach ${ }^{10}$. Mimo niedużych rozmiarów owego przejęcia jego głównym celem było pobudzenie działalności wydobywczej Sinochem. Aktywa firmy Emerald mają duży potencjał wzrostu, a wprowadzenie firmy Emerald do grupy Sinochem przyczyniło się do wzmocnienia jej pozycji zarówno na Bliskim Wschodzie, jak i w Ameryce Południowej. Ponadto jest to bardzo ważny krok w realizowanej przez chińską firmę energetyczną strategii budowania pozycji o zasięgu globalnym ${ }^{11}$.

\footnotetext{
${ }^{7}$ Geely Automobile Holdings Annual Reports , www.geelyauto.com.hk (16.02.2014).

${ }^{8}$ Volvo Car Group Financial Reports www.volvocars.com (16.02.2014).

${ }^{9}$ www.europe.autonews.com/ (1.03.2014).

${ }^{10}$ www.english.sinochem.com / dostęp 01.03.2014); www.reuters.com/ (1.03.2014).

${ }^{11}$ www.bloomberg.com/ (1.03.2014).
} 
Analizując dążenia chińskiego kapitału do dominacji na różnych rynkach, warto wskazać na kolejny przypadek przejęcia w sektorze energetycznym. Dotyczy on porozumienia zawartego w roku 2011 między największym w Chinach i piątym na świecie funduszem walutowym, China Investment Corp (CIC) a Gas de France Suez (GDF), będącym największym na świecie producentem i dystrybutorem energii elektrycznej, gazu ziemnego oraz energii odnawialnej, a przy tym również największym nabywcą gazu i importerem skroplonego gazu ziemnego w Europie. Pod koniec października 2011 roku firmy CIC oraz GDF Suez Gerard Mestallet podpisały umowę, na podstawie której CIC nabyło 30\% udziałów z wydobycia i produkcji firmy GDF Suez za sumę 2,3 mln euro, a także 10\% udziałów z upłynnienia obiektów GDF Suez Atlantic, znajdujących się w Trynidadzie i Tabago, o wartości $600 \mathrm{mln}$ euro. Gas de France Suez dodatkowo zobowiązało się zaopatrzyć China National Offshore Oil Corporation (CNOOC), tj. największego chińskiego off-shore producenta ropy, w statki umożliwiające przechowywanie i regazyfikację skroplonego gazu ziemnego. Ostatecznie umowa została sfinalizowana z końcem roku 2011. Porozumienie między firmami zmieniło układ sił konkurencyjnych na rynku, tj. wzmocniło pozycję CIC, a dla GDF było okazją do osiągnięcia dużych zysków. Głównym celem firmy wobec partnerstwa z China Investment Corp było wykorzystanie gwałtownie wzrastającego popytu w Azji na skroplony gaz ziemny oraz nawiązanie ścisłych kontaktów z tamtejszym przemysłem energetycznym w wyniku planowanej ekspansji ${ }^{12}$.

Dobrym przykładem zmian na rynku międzynarodowym w wyniku ekspansji chińskiego kapitału było przejęcie 100\% udziałów węgierskiego producenta izocyjanianów Borsod Chem Zrt przez największego producenta izocyjanianów w regionie Azji i Pacyfiku, Wanhua Industrial Group (Wanhua), które miało miejsce w roku 2011 w sektorze chemicznym. Chiński potentat wykupił wszystkie akcje jej dotychczasowych właścicieli większościowych, tj. Funduszy Permira i Vienna Capital Partners (VCP). Było to efektem restrukturyzacji finansowej węgierskiej firmy w roku 2010. Wanhua wsparła Borsod Chem funduszami w wysokości $140 \mathrm{mln}$ euro, które firma wykorzystała do budowy nowej elektrowni TDI-2 oraz wytwórni kwasu azotowego. Całkowite przejęcie Borsod Chem przez chińskiego inwestora, wspieranego przez federację z Bank of China na czele umożliwiło dalszy rozwój węgierskiej firmy w długim okresie, zapobiegając w efekcie masowym zwolnieniom.

Przedsięwzięcie nie tylko uratowało Borsod Chem od upadku, ale przede wszystkim doprowadziło do przemiany dwóch firm regionalnych w korporację globalną i otrzymanie miana trzeciego największego producenta izocyjanianów na świecie.

W efekcie przejęcia Wanhua stała się nowoczesną firmą, dysponującą wydajną technologią, sprawnymi liniami produkcyjnymi oraz oddanym zespołem pracowników. Funkcjonując w ramach struktury Wanhua Group, firma Borsod Chem jest odpowiedzialna za wszystkie realizowane na rynku energetycznym operacje. Wanhua ma przychylność ze strony byłych właścicieli większościowych, tj. funduszy prowa-

${ }^{12}$ www.chinadaily.com.cn / (18.02.2014); www.ft.com/ (18.02.2014). 
dzonych przez Permira oraz VCP, która wspiera chińskiego inwestora jako partner. Prezes Wanhua ma w planie powiększyć i wzmocnić przejętą firmę, aż stanie się ona nie tylko największym pracodawcą na Węgrzech, ale przede wszystkim największym producentem izocyjanianów w Europie, zapewniając jej stały rozwój ${ }^{13}$.

\section{Podsumowanie}

Obecnie stoimy w obliczu boomu inwestycyjnego chińskich przedsiębiorstw. Zaangażowanie Chin w projekty greenfield oraz nawiązywanie licznych porozumień na zasadzie fuzji i przejęć z zagranicznymi partnerami przyczyniły się do wzrostu osiąganych przeciętnych przychodów rocznych z 1 mln dolarów w roku 2000 do 3 mln dolarów w latach 2009 i 2010 i aż do 10 mln dolarów w roku 2011. Nawet bez mniejszych transakcji liczba chińskich inwestycji wynosiła wówczas 573. Gwałtowny wzrost zainteresowania Chin obcymi rynkami jest pobudzony przesłankami komercyjnymi. Dużą rolę w tym procesie odgrywają jednak również naciski ze strony ciągle rosnącej konkurencji na rynku krajowym oraz dostrzeganie ogromnych perspektyw rozwojowych na rynku europejskim. Można więc zauważyć wzmożoną aktywność chińskich inwestorów w krajach należących do OECD oraz w innych gospodarkach wysoko rozwiniętych. $Z$ jednej strony Chińczycy upatrują szansy na rozwój na rynku europejskim, z drugiej zaś chińskie inwestycje stanowią ogromne źródło dobrobytu dla Europy. Szacuje się, że do roku 2020 wartość chińskich bezpośrednich inwestycji zagranicznych sięgnie 1-2 bln dolarów, z czego UE-27 może uzyskać więcej niż 250 mld dolarów, czyli ok. 20-30 mld euro rocznie.

Chińscy inwestorzy zapewniają Europie nie tylko świeży kapitał, ale i pracę, podatki oraz efekty uboczne innowacji. Obecnie chińskie firmy zatrudniają już ponad 45 tys. Europejczyków, a biorąc pod uwagę komplementarność potrzeb chińskich inwestorów i wielkość europejskiej siły roboczej, zakłada się, że liczba ta będzie ciągle wzrastać. Przedstawione przypadki przejęć firm europejskich przez firmy chińskie są dobrymi przykładami ekspansji Chin, dążących do rozwoju i umocnienia swojej pozycji na rynku nie tylko lokalnym, ale i globalnym. Przedsięwzięcia te pokazują wspólny wysiłek firm chińskich i europejskich w dążeniu do rozwijania pomyślnej współpracy przy optymalnym wykorzystaniu wzajemnego potencjału.

\section{Literatura}

China deals. A fresh perspective, 2012, www.pwc.co.uk/china.

Geely Automobile Holdings Annual Reports, www.geelyauto.com.hk.

Grant C., Barysch K., Can Europe and China shape a new world order?, Centre for European Reform, 2008, http://www.cer.org.uk/publications/archive/report/2008/can-europe-and-china-shape-new-world-order.

${ }^{13}$ www.borsodchem-group.com / (18.02.2014). 
Hanemann T., Rosen D.H., China invests in Europe. Patterns, Impacts and Policy Implications, Rhodium Group, 2012.

Nawrot K.A., Kierunki inwestycji Chin. Jakich inwestycji chińskich może oczekiwać Polska, Poznań 2012.

Volvo Car Group Financial Reports, www.volvocars.com.

www.bloomberg.com.

www.borsodchem-group.com.

www.chinadaily.com.cn.

www.english.sinochem.com.

www.euccc.com.cn.

www.europe.autonews.com.

www.ft.com.

www.gochina.gov.pl.

www.imaa-institute.org.

www.news.xinhuanet.com.

www.reuters.com.

\title{
DIRECT INVESTMENT OF CHINESE ENTERPRISES ON THE EUROPEAN MARKET BRANCH IN THE CROSS SECTION OF INDUSTRIES
}

\begin{abstract}
Summary: The gradual expansion of the Chinese economy strengthens China's position on the international market. China dominates the world in terms of exports and direct investment of Chinese companies, aimed to developed European countries also increased significantly. The article will focus on the development of direct investment in European countries, especially in the developed European countries, with a focus on such countries as France, the United Kingdom and Germany. Chinese investors expect to achieve the highest revenue just in these countries. The purpose of this article is to present the location of Chinese direct investment in Europe, in the cross-section of industries, with a focus on selected examples of this type of agreements established between investors from China and European countries. Based on this, an attempt is made to determine the impact of mergers on the position of enterprises on the European market.
\end{abstract}

Keywords: foreign direct investment, mergers, acquisitions, Chinese expansion. 